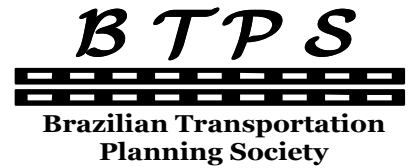

Journal of Transport Literature

Vol. 8, n. 3, pp. 7-36, Jul. 2014

Research Directory

\title{
Analysis of trip generating developments by space syntax - a case study of Brasília, Brazil
}

[Análise de polos geradores de viagens por meio da sintaxe espacial - estudo de caso em Brasília]

\author{
Ana Paula Borba Gonçalves Barros*, Erika Cristine Kneib, \\ Mariana de Paiva, Giovanna Megumi Ishida Tedesco \\ Technical University of Lisbon - Portugal; Lisbon, Federal University of Goiás - Brazil, \\ Federal Institute of Goias - Brazil, Federal Institute of Brasília - Brazil
}

Submitted 6 May 2013; received in revised form 30 Sep 2013; accepted 1 Nov 2013

\begin{abstract}
This article aims at analysing three Trip Generating Developments (TGDs), in different centralities of the Pilot Plan of Brasília, by using the Space Syntax Theory. It is our intention to study the location of these TGDs in terms of street hierarchy, potential for movement flow (syntactic indexes) and the traffic volume counts (Average Daily Traffic - ADT), taking into account the main roads that provide access to the TGDs. The choice of TGDs (Patio Brasil, Boulevard Shopping and Iguatemi) to be used in this analysis was based on the centralities found using the Delphi Method. It was verified that, according to Space Syntax, the TGDs occupy a rather strategic position within the whole system. This ratifies the importance of the use of this approach as a tool for urban planning, in order to complement other analytical strategies. Once the Space Syntax presents the movement potential in synchrony with the real flow in certain areas of a city, it is extremely relevant in helping choose the locations for implementing TGDs, be it in order to take advantage of existing centralities or to foster the development of zones there are not yet consolidated.
\end{abstract}

Key words: trip generating developments, space syntax, centrality, vehicular flows, Brasília.

\section{Resumo}

Este artigo visa analisar três Polos Geradores de Viagens (PGVs), inseridos em distintas centralidades no Plano Piloto de Brasília, por meio da Sintaxe Espacial. Objetiva-se verificar suas localizações quanto à hierarquia viária, ao potencial de fluxo de movimento (índices sintáticos) e ao volume de tráfego veicular (Volume Médio Diário - VMD), tendo em conta as vias de acesso aos empreendimentos. As centralidades encontradas por meio da aplicação do Método Delphi junto a especialistas serviram de subsídio para a seleção dos PGVs a serem utilizados em análises mais aprofundadas. Como achados, verificou-se que, segundo a Sintaxe Espacial, os PGVs ocupam posições relativamente estratégicas no sistema. Isso ratifica a importância do uso da abordagem como ferramenta de planejamento, podendo ser utilizada para complementar outras estratégias de análise. 0 fato de a Sintaxe Espacial apresentar o potencial de movimento em sincronia com o fluxo real em determinadas áreas de uma cidade demonstra sua relevância para auxiliar nas escolhas de localização para a implantação de PGVs, quer seja para aproveitar centralidades existentes, quer para impulsionar zonas ainda em fase de consolidação.

Palavras-Chave: polos geradores de viagens, sintaxe espacial, centralidade, fluxo veicular, Brasília.

*Email: anapaulabgb@gmail.com.

\section{Recommended Citation}

Barros, A. P. B. G., Kneib, E. C., Paiva, M. and Tedesco, G. M. I. (2014) Analysis of trip generating developments by space syntax - a case study of Brasília, Brazil. Journal of Transport Literature, vol. 8, n. 3, pp. 7-36.

- JTL/RELIT is a fully electronic, peer-reviewed, open access, international journal focused on emerging transport markets and published by BPTS - Brazilian Transport Planning Society. Website www.transport-literature.org. ISSN 2238-1031. 


\section{Introduction}

Some urban areas have a greater concentration of activities; therefore they draw more attention than other parts of the urban fabric and constitute what is called a centrality (Oliveira Jr., 2008). In the context of urban and transportation planning, the Trip Generating Developments have displayed a capacity of impacting the urban centralities, both in a good and a bad manner. When planned adequately, they may develop the social-economic potential of the region or otherwise, when poorly planned, they may result in relevant negative impacts to the spatial structure of urban settlements (Cf. Kneib, 2004; Kneib et al., 2010).

This paper considers the TGDs as developments that can contribute to form a new centrality or consolidate an existing one, thus being able to change the urban relations. Therefore, the characterisation of TGDs can contribute to the analysis of the impacts these developments have on the centralities in which they are placed. Moreover, the analysis of TGDs in a given centrality also has the potential to assist in planning or regulation for new TGDs in urban areas, taking into account the need to form new sub-centres or to consolidate existing ones. It is a way of fostering a better urban arrangement that, ultimately, offers better quality of life.

It is essential to characterise, identify and evaluate the TGDs in urban centralities in order to elaborate an urban plan that encompasses sustainable mobility. This joint analysis of the TGDs can help define a set of policies for transportation and overall displacements aimed at providing broad and democratic access to the urban space, by prioritizing non-motorised modes and public transport.

This meets the recommendation made by the Ministry of Cities (2004), which states that the Master Plan of a city should encourage the formation and consolidation of urban sub-centres. The study of urban centralities also contributes to researching the hierarchical relationships between different urban activities, taking into account the relational processes of land use and occupation.

It is in the context of the interpretation of spatial relations that the Space Syntax Analysis is used as a strategy to decode the performances associated with different arrangements that shape the urban space. Based on the Theory of Social Logic of Space, the Syntax investigates 
the way the elements of the city are linked together so that the parts can be analysed as belonging to a whole. This analysis focuses primarily on the topological view, because it is important to understand how these parts are articulated. Therefore this strategy can be associated with structuralism and a systemic perspective, since it seeks to understand the local and global impacts of changes in the urban structure (Medeiros, 2006).

In view of this, the use of Space Syntax is justified by presenting a complementary way to read the dynamics for urban studies in the area of transport, in which TGDs can be placed. Thus, the use of scientific methods to confirm certain results tend to strengthen the interdisciplinary characteristic, which is sometimes overlooked, in addition to expanding the scope of knowledge of a particular area of study. The interdisciplinary scenario thus enhances the way to analyse certain aspects addressed through new perspectives of study.

This study, therefore, aims to analyse the TGDs inserted into the urban centralities, by the application of tools related to the Space Syntax. The intention is to verify their locations in terms of street hierarchy, potential for movement flow (integration index) and the traffic volume counts (vehicles per day) in the access routes to the developments. Firstly, it is assumed that the location of the TGDs may improve its performance, if understood in terms of the dynamic relations in the city, emphasizing its importance as an element that may transform urban reality.

It is important to make clear, however, that the three TGDs chosen to represent TGDs in general (malls - Patio Brasil, Boulevard and Iguatemi) are all representatives of the same function - commercial. They are all part of the centralities identified by the experts, described in more details in the methodological procedures (Section 2). 


\section{Theoretical background}

\subsection{Urban Structures and centralities}

Initial models of urban structure were based in monocentric cities, as shown in the approaches of Alonso (1964), Muth (1969) and Mills (1972). Over time, the polycentric structure became more evident, being that its consolidation was shown in studies such as McDonald and McMillen (1990) and Anas et al. (1998).

Thus, centralization starts to be explained by several authors as a process in which there is the concentration of an activity or network of activities in the same space. It can be defined as a congregation of people and urban functions in a given urban centre, or functional areas, in search of certain economic, cultural or social benefits (Chapin, 1977; Castells, 1983). This spatial process creates the centrality or sub-centres, widely studied in the related literature. To illustrate, here are the definitions by Villaça (2001) and Giuliano and Small (1991).

Villaça (2001) calls sub-centre the diversified and balanced agglomerations of trade and services, other than the main centre, or even a replica in smaller size of the main centre. They may compete in some regards, but the sub-centre does not equate the main centre. According to the author, the polarizing and structuring power of a sub-centre is due to the complementary nature of the activities, since the greater the variety of shops and services available in the centre, the smaller the number of trips that a consumer needs to take in order to have all its needs met.

In another approach, Giuliano and Small (1990) point out that when the effects of traffic jams in central agglomerations become high, some activities tend to decentralise, being relocated to outside the central area. Due to forces of agglomeration, the activities tend to be concentrated in secondary clusters, called sub-centres by the authors.

Over the years, approaches and variables for defining the sub-centres have followed the same evolution of urban processes and dynamic. Initially, sub-centres were synonymous with concentration of jobs, evolving to models that considered other variables and other scales of analysis. According McMillen (2001 and 2004), the first formal procedure for identifying sub-centres was proposed in 1987 by McDonald. In this paper, the author defines the sub- 
centre as an area whose employment concentration indexes are higher than the adjacent zones. From then on, other works can be found in the literature that use other variables, such as density of trips (Gordon and Richardson, 1996; Kneib, 2008) or movement flow (Aguilera and Mignot, 2004) to identify centralities.

These facts corroborate the importance of land use, including the TGDs, and transportation systems in the analysis, definition and consideration in studies of centrality, due to its direct relationship with the variables mentioned - jobs, travel and flows. Moreover, it highlights the importance of testing other methods and variables for this purpose.

\subsection{Sub-centres and centralities: theory and process of urban structuring}

Amid the theoretical framework aimed at explaining the processes of urban structuring, this work focuses on functionalist theories, due to its close relationship with the transportation and land use, an approach which is strongly related to the object of study, the TGDs. According to functionalist theories, the spatial ordering of activities and their hierarchy are not random phenomena; they are governed by certain laws.

Under the classification 'functionalist', we have the theories originated from the work of Von Thunen, 1826: Alonso, Muth and Mills, which draw a relation between land revenue and distance (McMillen, 2001b; Baumont et al., 2004); the Wingo model (1961), which addresses issues relating to the value people give to time, place of residence and transportation technology, all of which are elements recognised for their importance, however, rarely considered in transport and land use policies; and the Lowry model, which seeks to explain the setup of urban residential areas and activity centres connected to them, with a focus on demographic concentration (Kneib, 2008).

Among the models and theories based on rules for ordering spatial activities, it is important to highlight the Central Place Theory of Christaller (1933), which provides a study of the size, function and spacing of market centres; the Losh model (1954) and Isard model (1956), which are based on the Central Place Theory; and the Growth Pole theory (Perroux, 1955), which considers the concept of the pole as an agglomeration or concentration of elements, so that a pole appears as a peak on a surface of homogeneous density, assuming the simultaneous existence of two or more poles (Kneib, 2008). 
Three points about the functionalist theories and their relation to the analysis proposed here should be noted: i) the functionalist theories consider laws that govern the spatial ordering of activities, with emphasis on the role of transport as a determinant for the location of these activities; ii) the theoretical approach of the relationship between transportation and land use and its importance to the urban structure; and iii) the approach of the location theories that explain the forces of attraction or repulsion contributing to the concentration or dispersal of the activities within the space.

\subsection{Space Syntax}

The Space Syntax is a theoretical and methodological approach, consisting of several techniques that seek to understand how the built environment, i.e., the shape of the city or part of it, interferes with movement patterns through their topological relationships - the study of spatial relations that take into account the relationship between space and pathways and regardless of size and shape - and not just geometry - description of physical components, such as dimensions, proportions, scales etc. (Medeiros, 2010).

The approach is based on the Theory of Social Logic of Space and comprises a set of tools for the configuration analysis of spaces, by which aspects of flow, transport and potential movement of pedestrians and vehicles in cities and buildings are investigated (Hillier and Hanson , 1984). Holanda (2001) adds that this approach is not just a set of tools, but "a theory, which implies a method, and a set of techniques."

Among these techniques, the one used in this study is the axial approach (whose focus is the streets), which is appropriate once it focuses on potential for movement flow of a given urban space. For the preparation of axial maps, the researcher goes through four stages: the linear representation of space (axial map/segments); the computerised analysis of the representation (mathematical matrix calculation); the correlations (association of axial map/segments with other data) and, finally, the simulations (new maps) (Hillier and Hanson, 1984; Medeiros, 2010). In the axial maps, after processing the mathematical matrixes, the movement potentials are represented by a color scale ranging from black - most integrated - to light gray - most segregated - going through shades of orange, green and light blue. The term 'most integrated' refers to street segments which are capable of congregating a higher movement potential, whereas the 'most segregated' refers to those which are less capable of doing so. 
It is worth mentioning that some studies have shown the strong correlation between the potential movement found through this analysis (which corresponds to the integration indexes obtained by axial maps, estimated by mathematical matrixes) and those observed in the field, such as, volumetric surveys or actual count of vehicular and pedestrian flow. In addition, there is also a correlation between integration and land use (Medeiros and Trigueiro, 2001), and between the actual count of vehicles and the integration index (Barros, 2006), among others.

The axial maps may also be used for local analysis, not only to global zones. This means that, depending on the purpose of the analysis, it is possible to use various radiuses in the processing range of the mathematical matrixes. These radiuses refer to the relation between the street segments of the system, i.e., the relationship of one street to all others in the system, in the case of a global analysis - radius $n(\mathrm{R} n)$-, or of one street with a given number of other streets, in the case of an local analysis, which may be, for example, the radius 3 (R3, or any other value) which will depend on the characteristics of the urban structure studied.

Another aspect to be highlighted concerns the integration indexes. As the urban structures are complex and different from one another, the resulting relationships between their parts are also different. Therefore, when comparing the average integration values of the structures, we tend to find variable measures, resulting from the peculiar ways of spatial organization. According to the arrangement of its components, a given system may foster or restrict movement, so the maximum and minimum integration values tend to vary and rarely coincide.

\section{Metodology}

In order to spatially analyse the urban sub-centres of the Pilot Plan of Brasilia, three methodological procedures were applied: (a) Experts Technique, developed by Kneib (2008); (b) Diachronic analysis of satellite images (Google) and traffic volume counts; and (c) Syntactic indexes from the Axial Maps (Space Syntax). 


\subsection{Experts technique}

This technique consists in consulting a panel of experts and qualified professionals in the field of Urban Planning and Transportation or community representatives with proven knowledge and experience in the area analysed, among others, for locating the centralities in a particular area of study, and for validating its importance or hierarchical distinction. Thus, experts identify and locate the centrality in maps, and attach to these a degree of importance. For each round of interviews, the information is treated statistically and a summary I containing the main considerations of the experts is prepared. As a result, a new map is generated, containing the sub-centres identified from the statistical treatment (median) and their degrees of importance. This process should be repeated until the experts have reached a consensus on the existing sub-centres in the area under study (Kneib, 2008). The accuracy of the result of the research depends on the experts' knowledge about the area under study. The map derived from this research, containing the centrality identified by experts, was the basis for the choice of TGDs to be analysed in detail - Patio Brasil, Boulevard Shopping and Iguatemi - featured on the items that follow.

\subsection{Satellite Images and traffic volume counts}

At this stage, after the choice of TGDs, we used satellite images (Google Earth), in order to identify the changes in the urban footprint, resulting from the implementation of the developments. The changes in the proportions of occupied land (private areas) and empty land (public areas) were read diachronically.

In addition, the data about the traffic volume counts in the most important streets closest to the developments was taken from the Traffic Department of the Federal District (DETRANDF) and the Department of Roads (DER-DF), in order to check whether there were changes in the flows of vehicle after the implementation of the developments. However, for reasons of absence of some data (described below), we used the one closest to the reality required (e.g. roads as close as possible to the development), so as not to interfere with the reliability of the survey results. 
Initially, it should be noted that for the year 2012 there already were speed radars on the streets near the TGDs, which means there is data for the three projects under study. However, for the previous years the data does not coincide, since there is a time difference for when radar equipment was placed in each of the points under study. For Patio Brasil and Boulevard, the oldest data was collected in 2008, and for Iguatemi it started in 2009.

The period for data collection chosen was April, because it is considered a typical month. The weekdays chosen were Tuesdays, Wednesdays and Thursdays (for the same reason), except when these were holidays or came before public holidays, which were excluded so there wouldn't be inconsistencies. Based on this, 12 days (of April) were used for data collection in each point, providing therefore a homogenous analysis.

It is important to highlight that, although the methodology of TGDs suggest the use of weekends for the analysis of vehicular flow, we preferred to use the days of the week because we could verify some issues of inconsistency in the data pertaining the weekends, due to technical problems in the electronic equipment. The decision was further endorsed because the variation of flows pre and post occupation followed the same proportion, both on weekdays and weekends.

The point where the data was collect also presented some specific characteristic that are noteworthy.

For Patio Brasil the first count conducted in W3 South (the street that passes in front of the mall) was in 2007, though only in a South-North orientation. Therefore we chose to use data from the following year (2008), since there are records for both directions (South-North and North-South), using therefore the average of the two directions.

For the street in front of Boulevard Mall, as there is no electronic equipment at the end of W3 North (exactly in front of the entrance of Mall), it was decided to make use of the nearest point of the W3 North, situated on superblock 514 North. It is known, however, that due to a distance of approximately 1,000 meters, there is the possibility of consistency problems. However, we preferred to use the data of the closest street to having to discard the values and thus fail to use the data. 
And finally, for Iguatemi, the data about DF009 or EPPN roads was used (Estrada Parque Peninsula Norte). However, because there is no sequential data for a single electronic device, we decided to use the following criteria: (a) for 2009, the data used was from $\mathrm{Km} 1.3$ (eastbound), once the first vehicles counting was on October $17^{\text {th }}, 2007$ and the last in December, 2011; and (b) for 2012, the data used was from Km 1.8 (westbound), once the first vehicles counting began only on February $22^{\text {nd }}, 2012$.

The dates of the satellite images taken was chosen to correspond with the date in which the vehicular flow was registered: for Patio Brasil, 2008 and 2012; for Boulevard, 2008 and 2012; and Iguatemi, 2009 and 2012. It is noteworthy that for the two latter, whose inauguration was in the year of 2009 and 2010, respectively, the analysis pre and post occupation was not compromised; however, to the first, as there was no electronic equipment at the time of its construction (1997), it not was possible to analyse its impact on the flow of the immediate surroundings.

\subsection{Axial Maps}

For this last and essential methodological step, we used the axial maps of the Federal District (DF) already ready and derived from the database of the study group Morphological Dimensions of the Urbanization Process (DIMPU-UNB). For the process of preparing the map (Figure 1), (A) only the basemap of the site under study is needed in order to (B) drawn the lowest number of straight lines within the street network and then (C) export to the program Depthmap, in which the syntactic analyses are carried out, both globally and locally (cf. Barros, 2006; Medeiros, 2010). Since the goal of this research is to study not only the urban context of the DF, but also specific aspects of the areas surrounding the TGDs in question, we decided to use radius $n$ and radius 7 , because we noticed it was better suited for the fragmented structure of the DF, in view of the correspondence with the centrality (Barros et al. 2011). 

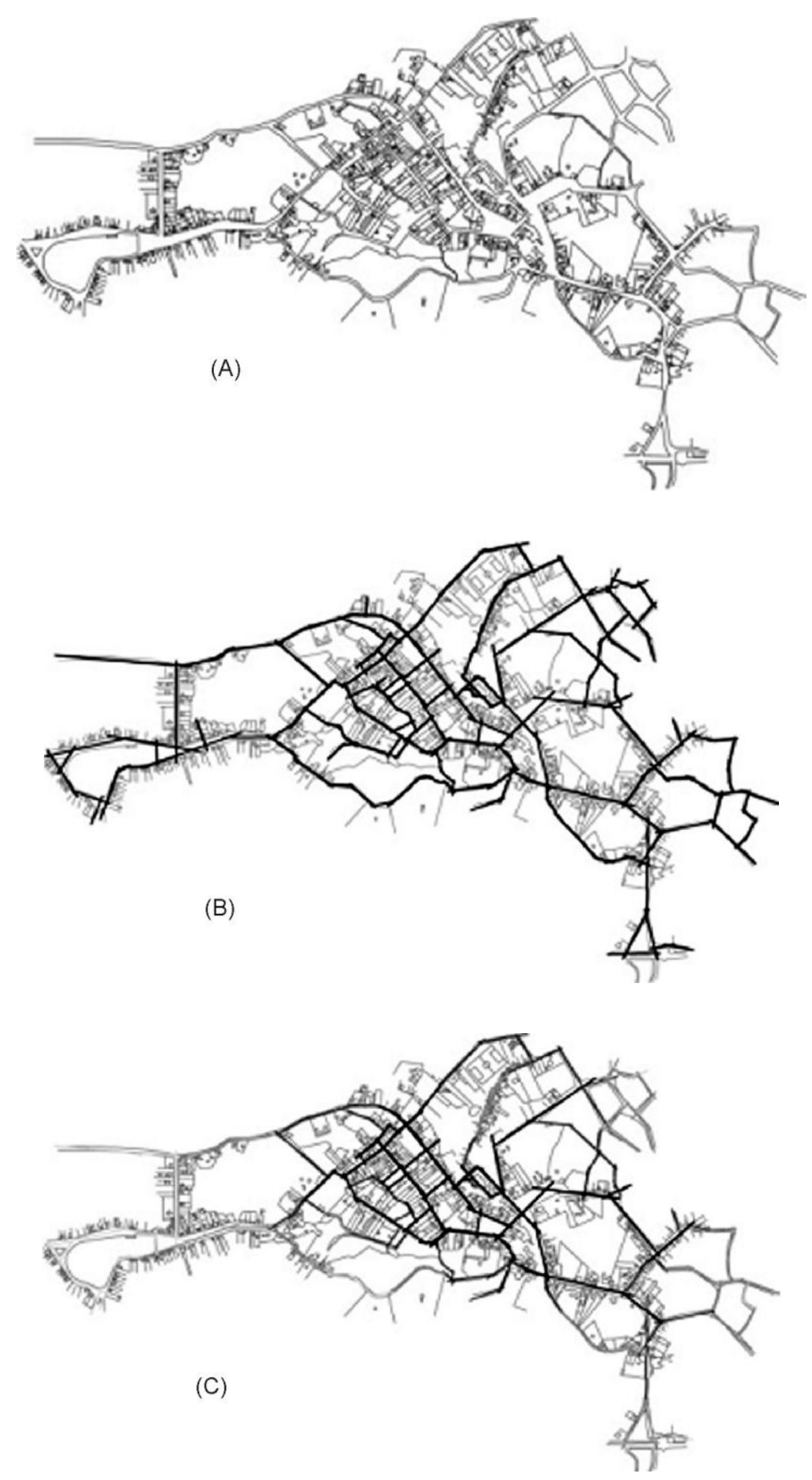

Figure 1 - Process of drafting the axial map for the city of Tiradentes (MG) ${ }^{1}$

\footnotetext{
${ }^{1}$ Source: Medeiros (2006).
} 
After the models were drafted using axial maps, four syntactic indexes were used: (a) Global Integration - topological relation between all streets of the system with one another, (b) Local Integration - topological relation between all streets of the system and all the streets closest to them, depending on the radius to be chosen (in this case, after experimenting, we adopted the radius 7); (c) Connectivity - number of existing connections of each street of the system, and (d) Synergy - the degree of synchrony between the values of global and local integration, in which the dependence of one variable towards another is evaluated, ie, a system is considered to have more synergy than another when the global hierarchical structure (analysed using radius $\mathrm{n}$ ) is closer to the local hierarchical structure (analysed using radius 7). For this last index (synergy), the street axis within a 1,000 m radius from the centre of the polygon in which all TGDs can be found was analysed.

\section{Procedure and Results}

In order to identify urban centralities, we chose the Pilot Plan of Brasilia, because it is an exemplary site for urban mobility and therefore to the implementation of policies related to the theme.

\subsection{Characterisation of the area under study}

The Pilot Plan of Brasilia, designed by urban planner Lucio Costa, has its urban design guidelines in accordance with the Athens Charter, which laid the foundations of modern urbanism - the city is structured around four basic functions: dwelling, work, transport and recreation.

Nowadays, the Pilot Plan, which corresponds to one of the 31 Administrative Regions (RA) of the DF (Administrative Region 1, or RA - 1), has a population of more than 280,000 inhabitants, out of a total of 2,570,160 residents for the entire Federal District (IBGE, 2010).

The street network of the urban settlement was primarily structured upon two axes intersecting at a right angle, as a cross, a reference made by urban planner Lucio Costa to the Portuguese urban conceptions. The urban structure shows the repetition of basic elements, in the form of a curved beam of parallel arteries leading to the residential area, orthogonally 
intercepted by a straight avenue, called Monumental Axis, where the major public buildings are located (Holanda et al., 2003).

Arraias (2007) attributed to Brasilia the characteristic of being polynuclear, fragmented and multifunctional. This fragmentation is strongly present due to the existence of surrounding cities that lie beyond the limits of the Pilot Plan, and do not represent a continuum of the Pilot Plan. The populations of these cities daily commute to the Pilot Plan and other surrounding cities for purposes of work and study, so the Pilot Plan can be considered a pole that attracts trips, while the surrounding settlements can be considered dormitory cities.

\subsection{Results}

The methodological procedure proposed above was applied to spatially analyse the urban subcentres of the Pilot Plan of Brasilia and check if their locations are consistent with regard to street hierarchy, the potential for movement flow (syntactic indexes) and the volume of vehicular traffic (Average Daily Traffic - ADT) in the streets leading to these developments.

\subsubsection{Expert technique}

In this phase, ten experts with training and experience in urban and transportation planning who know the area under study were selected to participate in the study based on the Delphi Method. On a map of the Pilot Plan of Brasilia, these professionals outlined the centralities and assigned a degree of importance to each one, whose values ranged between 1 and 7 using only odd number (Figure 2) where 1 would be the lowest grade and 7, the highest. After the statistical treatment of the responses to the first round, a second map was drafted, now containing the sub-centres identified by all the participants and their degree of importance. These were repeatedly analysed until all experts reached a consensus. It is important to mention that it took two rounds to reach the result obtained in Figure 2, with all sub-centres and their degrees of importance identified. 


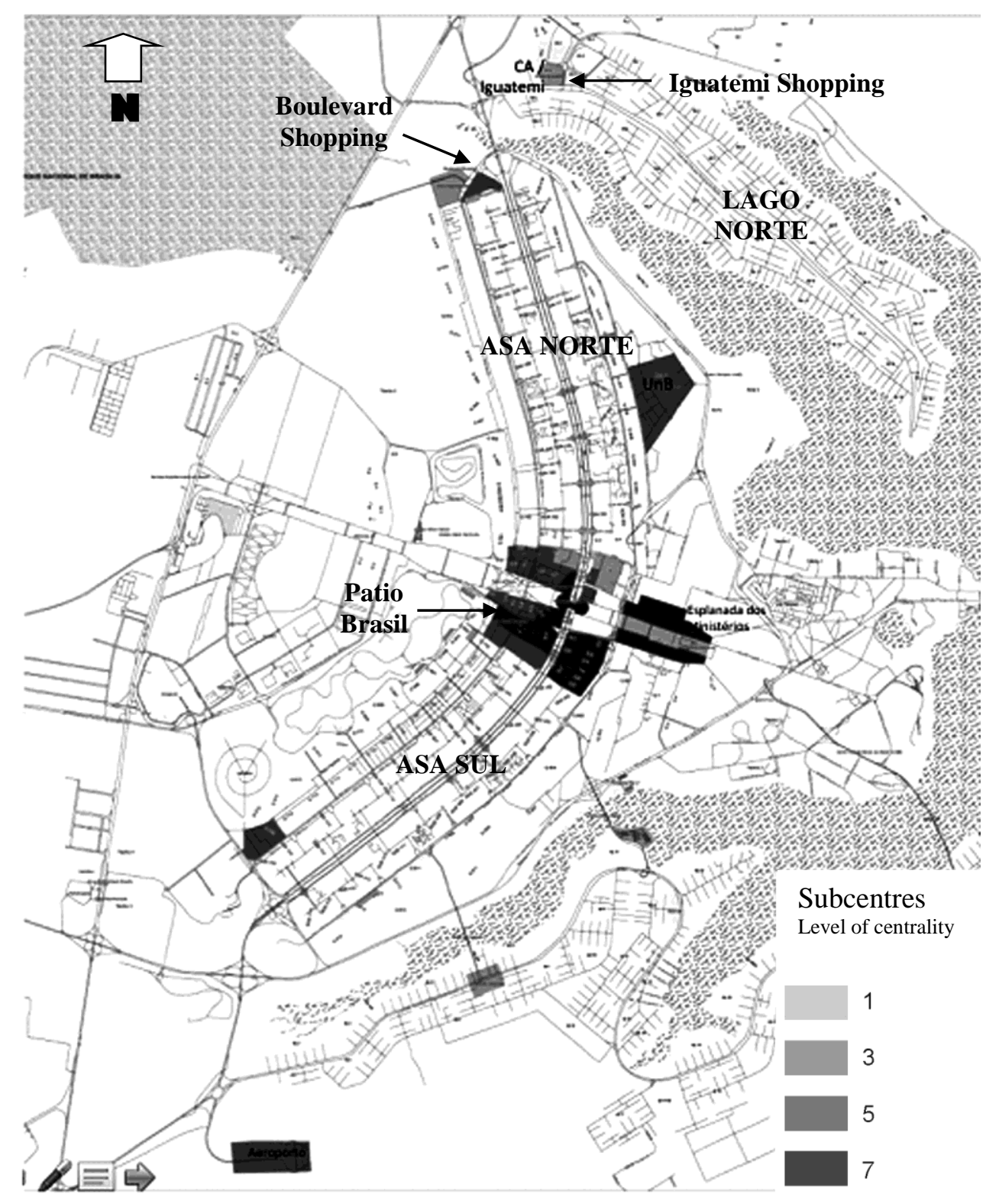

Figure 2 - Identification and degree of importance of the sub-centres of Brasília's Pilot Plan.

The centralities indicated by the experts were: (i) Esplanada dos Ministérios (Monumental Axis), (ii) Setor Comercial Sul (SCS)/Shopping Patio Brasil (South Commercial Sector/ Patio Brasil Mall), (iii) Setor Hoteleiro Sul (SHS)(South Hotel Sector), (iv) Centro de Atividades (CA)/Shopping Iguatemi (Activity Centre/Iguatemi Mall), (v) Setor Hospitar Sul (SHS)(South Hospital Sector), (vi) Setor Hospitalar Norte (SHN)(North Hospital Sector), (vii) Supermercado Extra/Boulevard Shopping(Extra Supermarket/Boulevard Mall), (viii) Setor Hoteleiro Norte (SHN)(North Hotel Sector), (ix) Airport, (x) Universidade de Brasília 
(UnB)(University of Brasília), (xi) Complexo de Restaurantes na altura da Ponte JK (Juscelino Kubtischek)(Restaurant Complex of the JK Bridge), (xii) Centro Comercial Gilberto Salomão (Lago Sul) (Commercial Centre Gilberto Salomão), (xiii) Brasília Shopping, (xiv) Setor de Autarquias Sul (SAS)(South Local Government Agencies Sector), (xv) Setor de Autarquias Norte (SAN)(North Local Government Agencies Sector), and (xvi) Rodoviária do Plano Piloto (Pilot Plan Buss Terminal).

Among these indications, we decided to research only three TGDs located in different centralities, so that it was possible to perform further analysis representing different consolidation processes. The places chosen were: Setor Comercial Sul (SCS)/Shopping Patio Brasil (South Commercial Sector/Patio Brasil Mall), which is considered a consolidated centrality; Supermercado Extra/Boulevard Shopping (Extra Supermarket/Boulevard Mall); and Centro de Atividades (CA)/Shopping Iguatemi (Activity Centre/Iguatemi Mall), the two latter being considered centralities undergoing a consolidation process. All developments chosen are representative of the same function - commerce.

Figure 2 shows the degree of importance of the sub-centres in the Pilot Plan of Brasilia obtained through expert analysis. It can be observed that the centrality where Patio Brasil is located was awarded the highest degree of importance, in relation to the others. Probably, this result is a consequence of its central location in the spatial structure of the Pilot Plan and/or also because it has been functioning since 1997. Moreover, Patio Brasil lies in the South Commercial Sector, which belongs to the first central area of the Pilot Plan, implemented in 1960.

\subsubsection{Satellite images and traffic volume counting}

In this second phase, we sought to compare images from Google Earth - from 2008 and 2012 for Patio Brasil and Boulevard malls, and from 2009 and 2012 for Iguatemi Mall - in order to analyse the changes in the urban occupation over that time. The images used in this comparison are available in Figures 3, 4, 5, 6, 7 and 8.

From the result of the map of the 2nd round (Figure 2), it is observed that the region in which the mall Patio Brasil lies is characterised as a consolidated centrality due the presence of offices, shops, etc. in the region and it was enhanced with inauguration of the mall in 1997. 
Such consolidation is confirmed by comparing the images of 2008 and 2012 (Figures 3 and 4) of Google Earth, which shows the existence of the TGD, in addition to the South Commercial Sector (SCS), South Radio and TV (SRTVS), South Hotel Sector (SHS) and South Hospital Sector (Hospital de Base and Sarah Kubitchek).

In the latter image, a new development can be seen (the building Parque Cidade Corporate in Figure 4) near Patio Brasil. However, there was no interference with the flow of vehicles in the area, as it will be explained in the following paragraph. The data confirms that the development helped to consolidate the existing centrality; however, apparently it did not change the spatial urban structure of the surroundings.

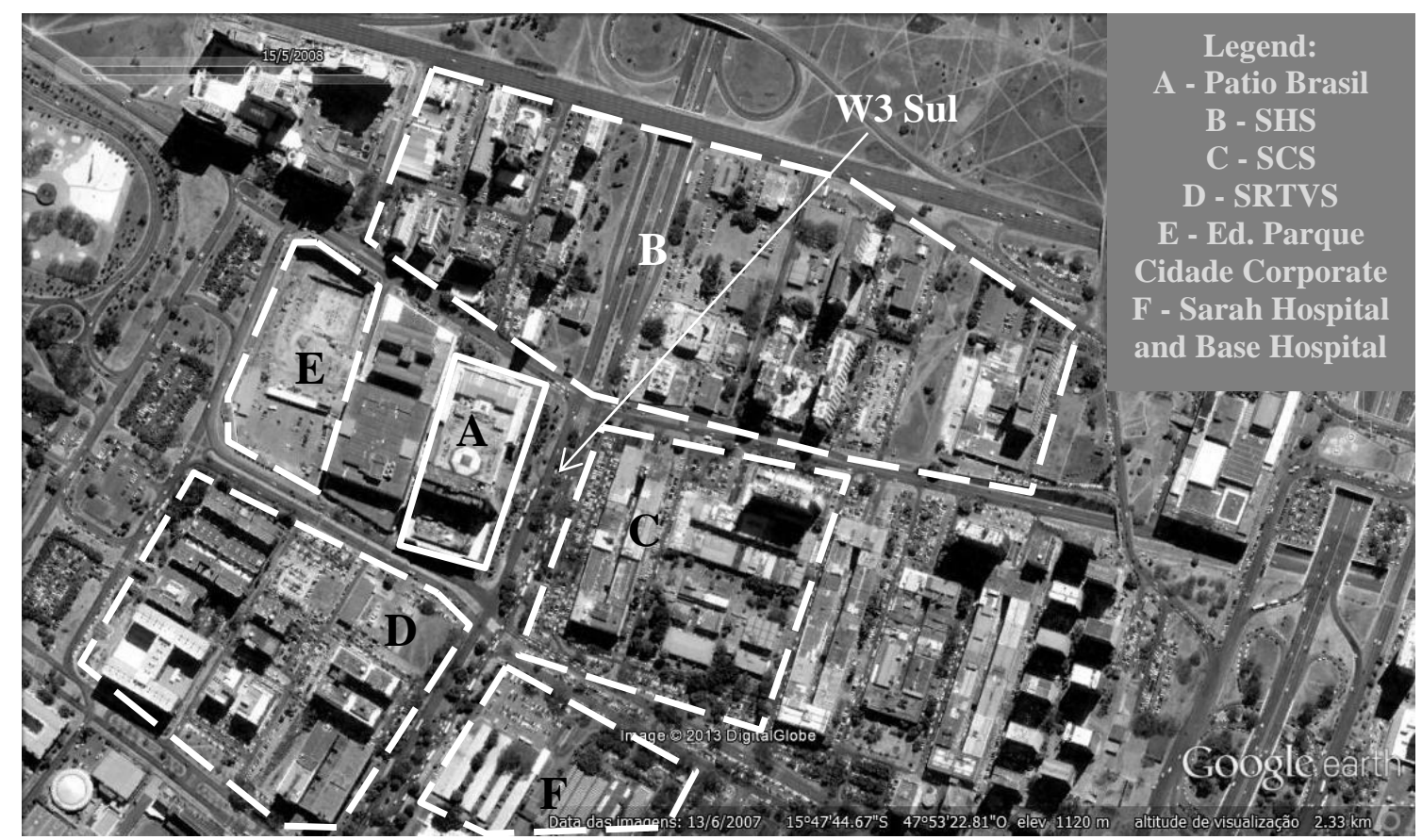

Figure 3 - Location of Patio Brasil. Source: Google Earth (2008)

It appears that in 2008 there was an average daily volume of 23,226 vehicles in the month of April, in the street W3 South and in 2012 the flow dropped to 19,639 ADT (Table 1). This corresponds to a $15 \%$ decrease, which may be the result of changes to specific aspects, such as weather conditions and, therefore, affecting "the reduction in speed, increase of the headway between vehicles, and consequent reductions in the saturation flow" (Goodwin, 2002). 
Another example of a centrality is the one at the end of the North Wing - where there is the Boulevard Mall, the EXTRA supermarkets, Wal-Mart and Atacadão, and the North Hospital Sector. It is known that the area was originally designed to house a public transportation terminal (which in 2008 existed, but it was not adequately structured to suit its functions). However, the government issued the Law no. 3.719/2005, which ordered the change of function of the site, giving way to the Boulevard Mall with the supermarket Carrefour (Figure 5 and 6).

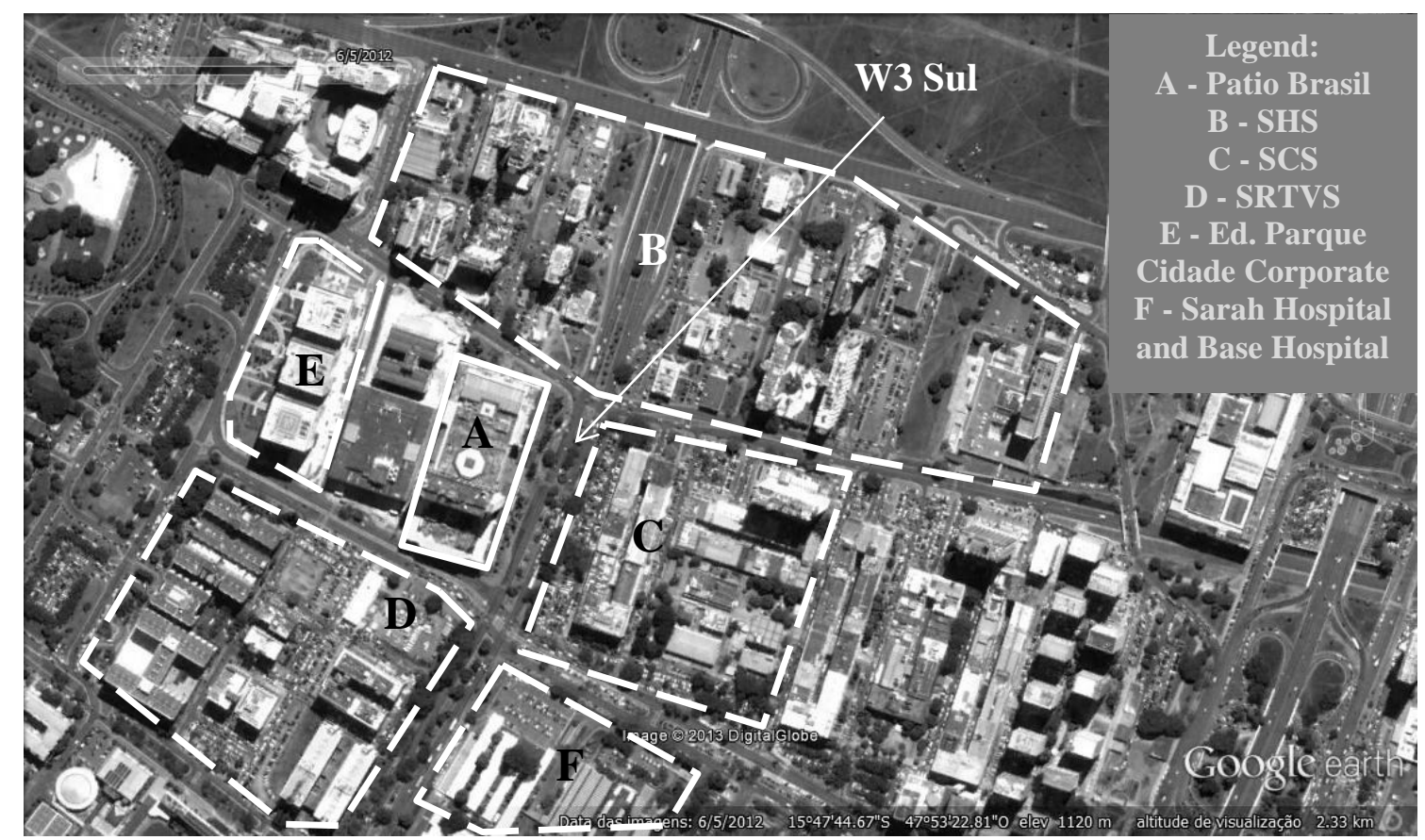

Figure 4 - Location of Patio Brasil. Source: Google Earth (2012)

Despite the emergence of new developments (Wal-Mart, Atacadão, Chevrolet and Carrefour/Boulevard - Figure 6) in the centrality that already existed on W3 North, there was a decrease in average daily vehicular traffic between April 2008 and 2012, from 16,335 ADT to 11,794 (Table 1). This corresponds to $27 \%$ decrease, which may result from alterations also related to climatic conditions, however, they may also be related to the placement of the electronic speed radar once it is located at Super Quadra 514 North and Boulevard is located at Super Quadra 516 North. At the location of the speed radar there are no developments that would attract/generate trip.

It appears, therefore, that the emergence of these new developments did not seem to have influenced vehicular traffic at the end of W3 North: perhaps because they are businesses that 
compete against each other, thus distributing a vehicular flow that would not increase, or possibly, because there already was the Extra Supermarket, which already boosted the traffic in the region.

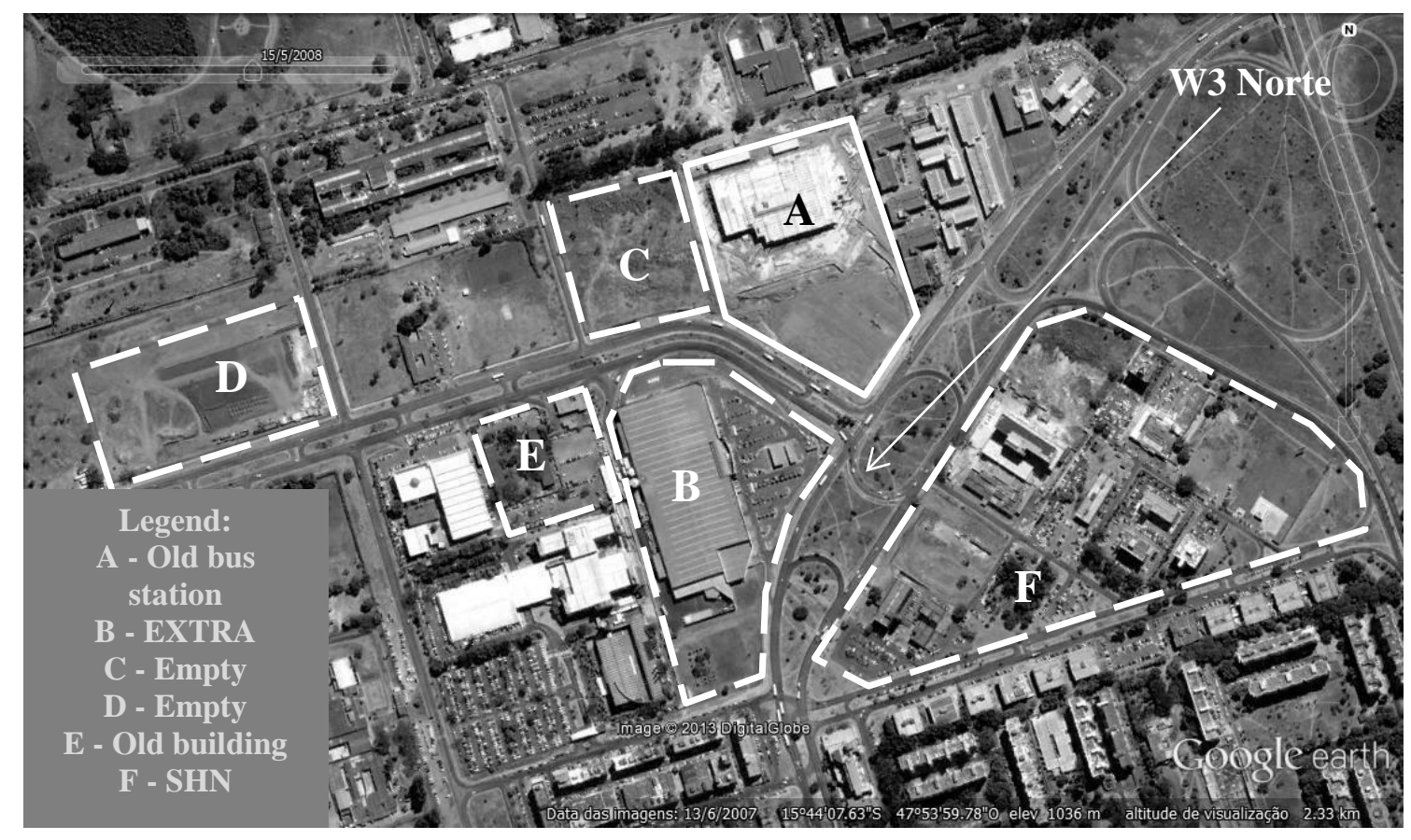

Figure 5 - Location of the old bus station. Source: Google Earth (2008)

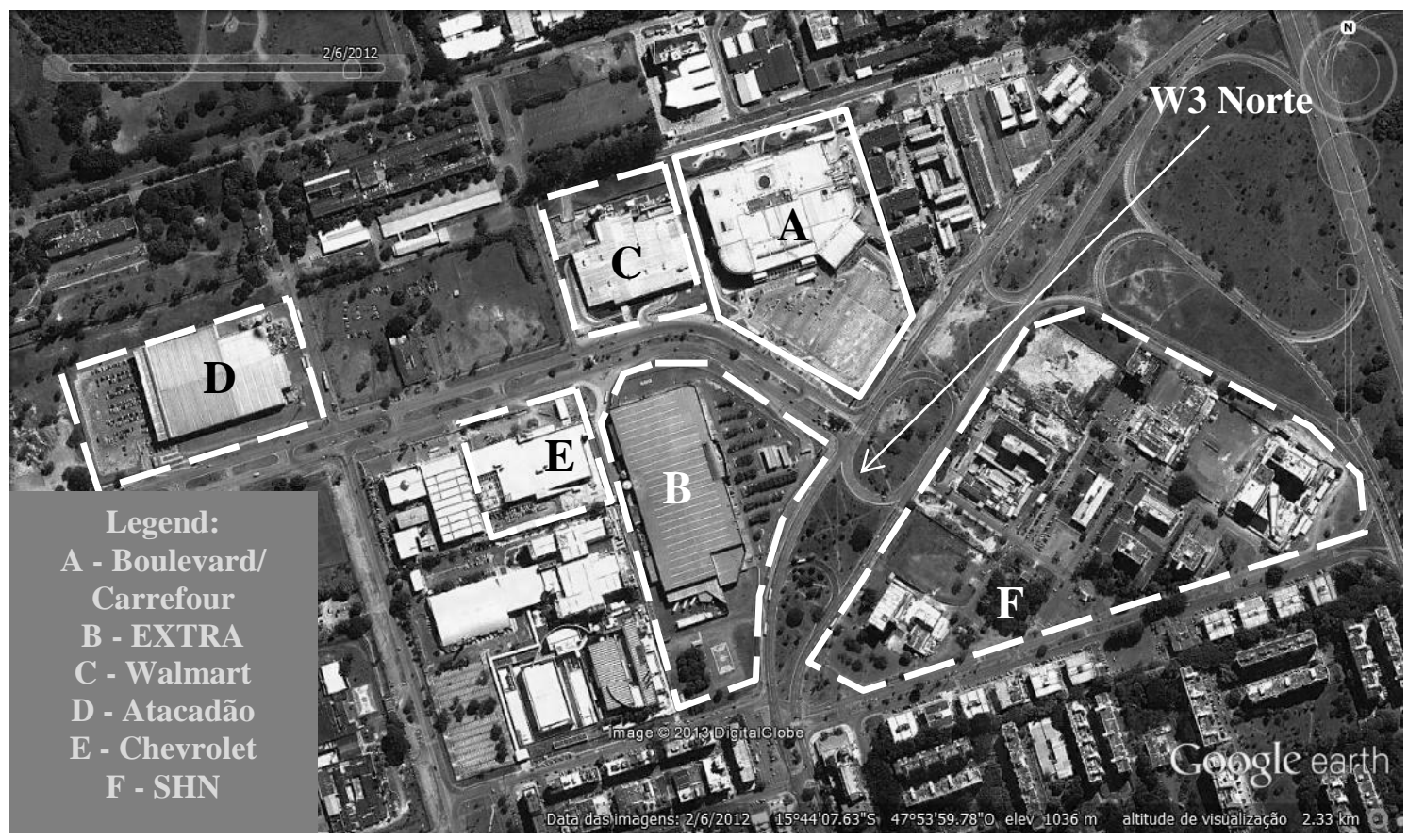

Figure 6 - Location of Boulevard Shopping Mall. Source: Google Earth (2012) 
Finally, the experts also indicated the area where today stands the Iguatemi Shopping Mall, at the beginning of Lago Norte (North Lake side) as a centrality. In this area there was a construction which was abandoned for some years (Figure 7). The surrounding region has the characteristic of mixed use, mainly due to the Activities Centre (CA), which gathers housing, trade and services. There is also a shopping mall - Deck Norte - which is smaller than Iguatemi Mall and supplies the area since 2007, apparently losing its relevance today.

Table 1 - Data from the traffic volume counts in the streets close to the TGDs

\begin{tabular}{cccc}
\hline & \multicolumn{2}{c}{ Data from Traffic Volume Counts } \\
\hline TGDs & Place of counting & Years & Average Daily Traffic in April - ADT \\
\hline Patio Brasil & W3 South - SCS & 2008 and 2012 & 23.226 and 19.639 \\
Boulevard & W3 North - 514N & 2008 and 2012 & 16.335 and 11.794 \\
Iguatemi & EPPN - Km 1,3 & 2009 and 2012 & 21.294 and 38.369 \\
& and 1,8 & & \\
\hline
\end{tabular}

In Figure 7 we can see that in 2009 the occupation of CA was not very dense, however, even before the implementation of Iguatemi Mall, the area was going through a constant process of growth. It is believed that with the inauguration of the Mall (in 2010), this process has been accelerated.

The analysis resulting from the comparison between the vehicular counting of 2009 (pre Iguatemi Mall) with 21,294 ADT and of 2012 (post Iguatemi Mall) with 38,369 (Table 1), shows that there was a very significant increase in traffic in the area (80\%). As this is a segregated area (as Figures 7 and 8 can demonstrate), we can safely consider that this increased flow was fostered by the implementation of this TGD.

Therefore, the comparison between satellite images and the counting provided satisfactory but not entirely convincing results, especially in relation to the centralities where Patio Brasil and Boulevard Mall are located. For the first case, it would be essential to analyse counts prior to 1997 (inauguration of the project) on all streets that allow access to the development, so as to understand the actual impact that it had on the surroundings; and for the second, the fact that there is no data for the streets directly connected to Boulevard Mall does not allow a precise reading of its interference in its immediate surroundings. For the situation of Iguatemi the 
results, although derived from two different units were satisfactory, since these are located on a stretch of road that has no connections that may cause significant interference to the flow.

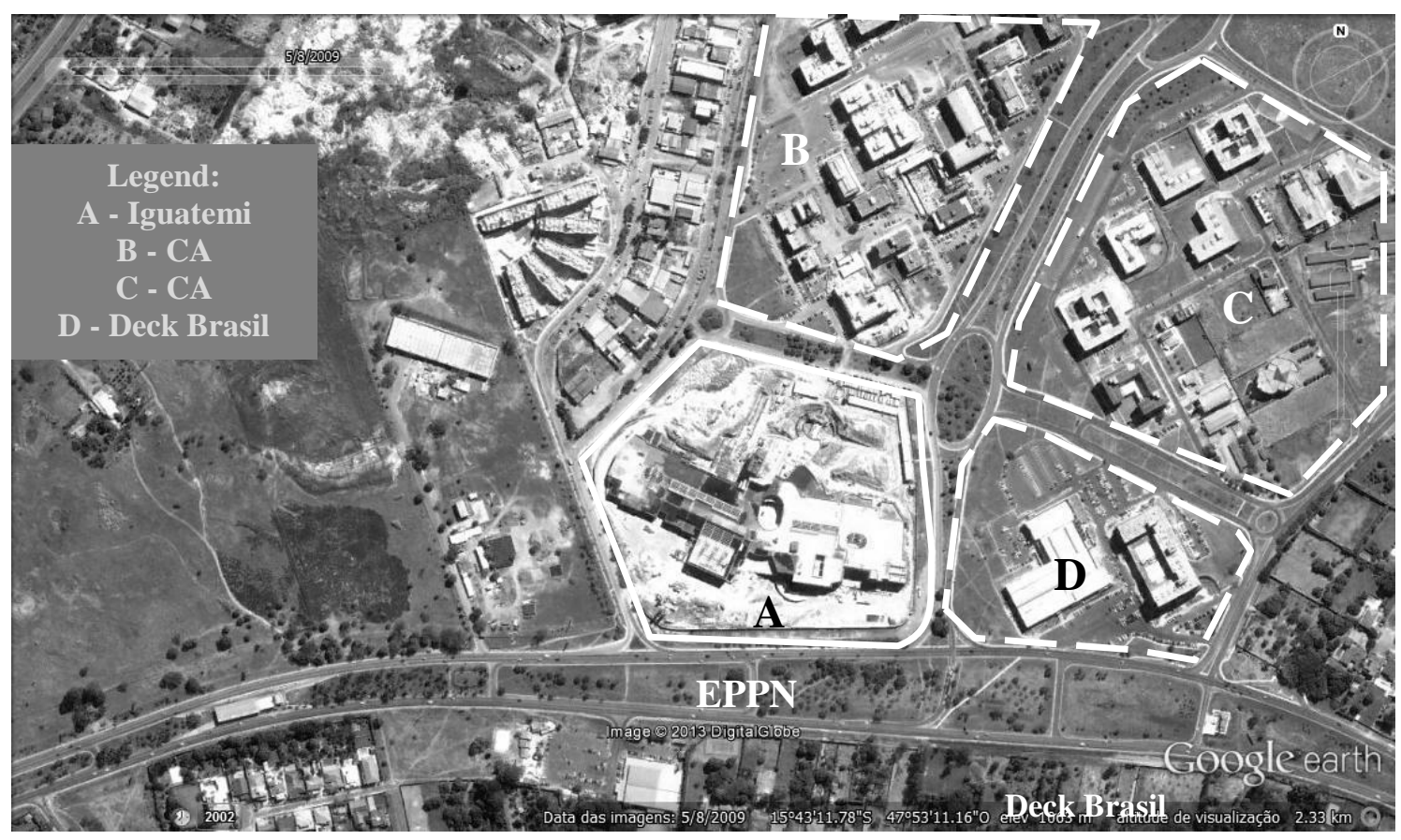

Figure 7 - Location of the area where Iguatemi Mall was built, with the old abandoned construction site. Source: Google Earth (2009)

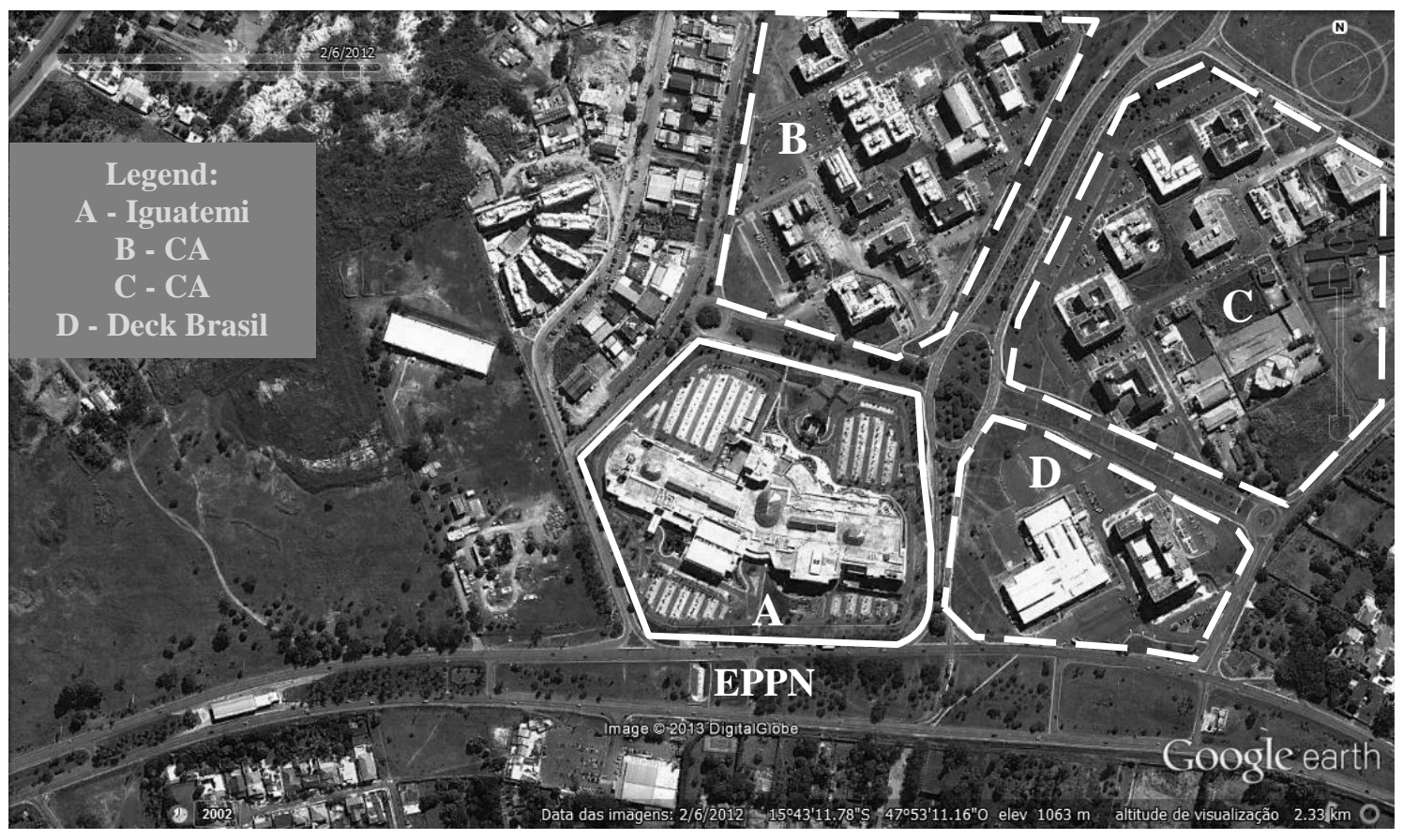

Figure 8 - Location of Iguatemi Mall. Source: Google Earth (2012) 


\subsubsection{Axial Maps}

For the last phase of this study, we used the Space Syntax in two levels: (a) the global axial map (Rn) of the Federal District and RA 1 (Figure 9) in order to contextualise the study, and (b) the local axial map (R7) to characterise the three TGDs in order to identify their potential use in terms of road accessibility based on the shape of the city of Brasilia.

Before starting the analysis of the spatial configuration, it is worth clarifying that TGDs are considered polygons and the relationship with the Space Syntax is performed by means of the street axes that pass near these polygons. Therefore, only the most integrated axes are used for the interpretation, linked to the polygonal of the TGDs (Patio Brasil: W3 South, Boulevard Shopping Mall: W3 North, and Iguatemi Mall: DF009 or EPPN - Estrada Parque Peninsula Norte).

Using the syntactic analysis, it is possible to find several integrated areas, which correspond to the configuration centres and were compatible with the centralities detected by the experts technique. It is noteworthy that in the map R $n$ (Figure 9) of the DF, most RAs are somewhat integrated into the global system (predominantly light gray colors), i.e., the urban structure of the DF as a whole. This happens, as highlighted by Medeiros (2006), due to the absence of connections in the urban fabric: the DF has as main feature a structure of isolated islands (cities/districts) that are articulated mainly by structural streets, in this case, EPIA (Estrada Parque de Indústria e Abastecimento), EPTG (Estrada Parque Taguatinga Guará), EPNB (Estrada Parque Núcleo Bandeirantes), among others (Figure 9).

It must be noted that the high integration of these roads - EPIA (1.17), EPTG (1.11), EPNB (1.15) - in relation to the system as a whole (hence use of back color), located in the third quartile (highest quartile of integration values), reinforces the polarization of the system, emphasizing the emergence of more segregated spaces and a labyrinth configuration (derived from the shape of the city). 
For the three TGDs chosen by the Experts Technique, the values of global integration obtained were: Patio Brasil - global integration (0.83); Boulevard Shopping Mall - global integration (0.94); Iguatemi Mall - global integration (0.87), as shown in Table 2. These results show that for the set of possible paths to be taken from the TGDs to all other streets in the system, the ones from Patio Brasil are the deepest, i.e., those that require a greater amount of changes of direction. On the other hand, the ones for Boulevard Mall are the most shallow, which indicates a place on average more accessible, followed by Iguatemi Mall.

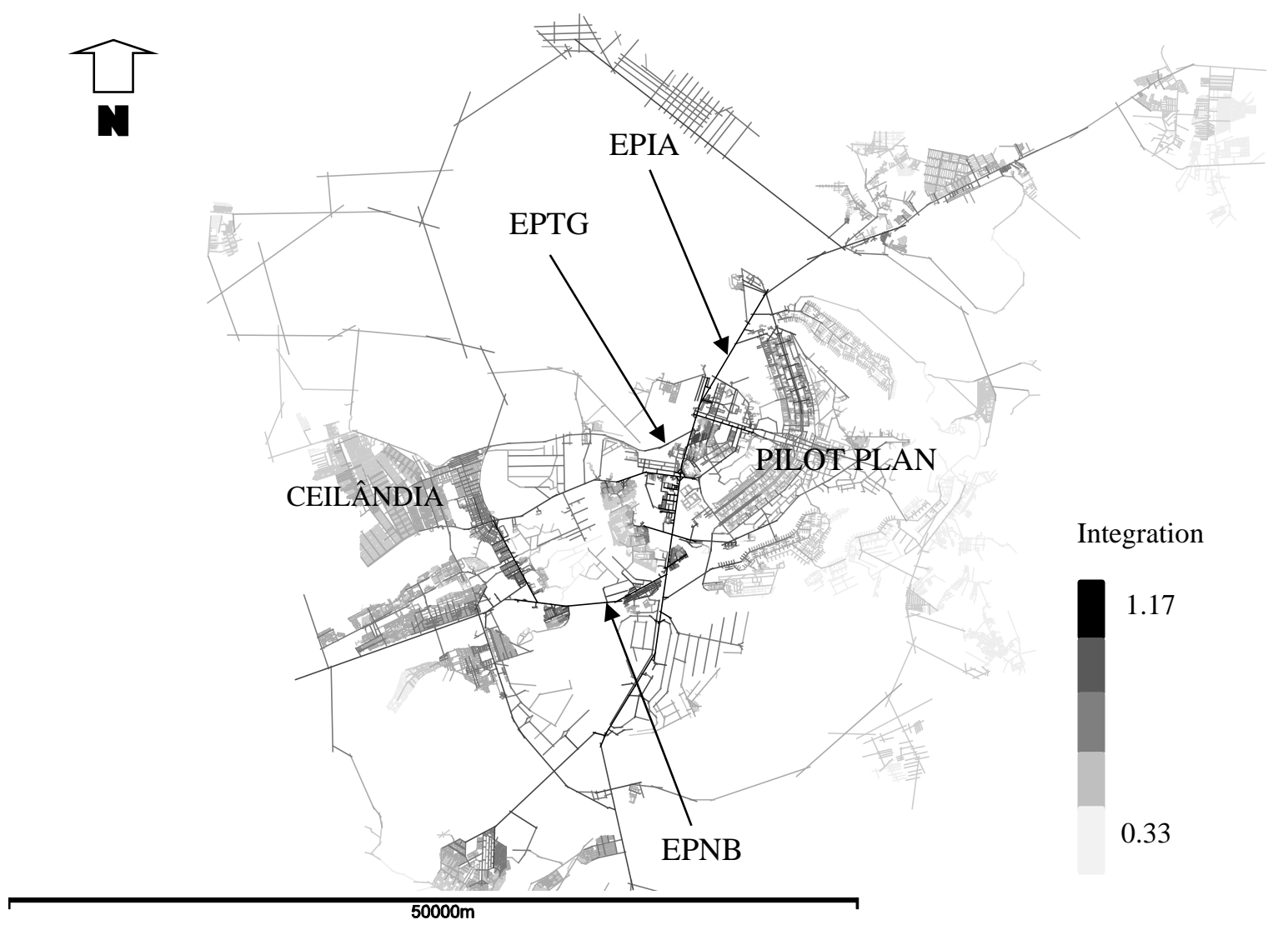

Figure 9 - Axial Map Rn of Federal District (partial). Source: DIMPU/UnB study group (2009).

Overall, therefore, Boulevard Mall is easier to reach. This happens due to the locations of the TGDs, because Patio Brasil lies within the mesh of the Pilot Plan, whose characteristics are an ordered but not very intelligible system (according to its plan). On the other hand, the other two malls are located in areas next to the EPIA, which plays a primary role in the accessibility system of the DF, which implies a smaller number of turns to be performed when trying to go from these TGDs to the other streets in the system, more especially those integrated to the DF. 
Once none of the TGDs under study are located in the high global integration streets, the local analysis (radius 7) becomes of greater importance for specifically understanding the phenomenon.

For the specific analysis of the TGDs, it is found that locally (Radius 7 - Figure 10), the integration index of the streets where the TGDs are located is higher than the global one (Table 2) - Patio Brasil (1.69), Boulevard (1.80) and Iguatemi (1.62). This is based on the close relationships of these axes with the neighboring streets, at a distance of seven steps/turns, which in turn leads to a greater importance of each street over the immediate surroundings of the system.

For the interpretation of the urban system from a local perspective, emphasis should be given to two streets - Hélio Prates Avenue (2.55) and Via P Um Street (2.38) - both located in Ceilândia (Figure 11), as they are the most integrated in relation to the entire system on a local scale.

Table 2 - Syntactic indexes of the streets where the TGDs are located

Trip Generating Developments

\begin{tabular}{cccc}
\hline Integration Value & Patio Brasil & Boulevard Shopping & Iguatemi Shopping \\
\hline Integration R $n$ (Global) & 0.83 & 0.94 & 0.87 \\
Integration R7 (Local) & 1.69 & 1.80 & 1.62 \\
Conectivity & 8 & 7 & 5 \\
\hline
\end{tabular}




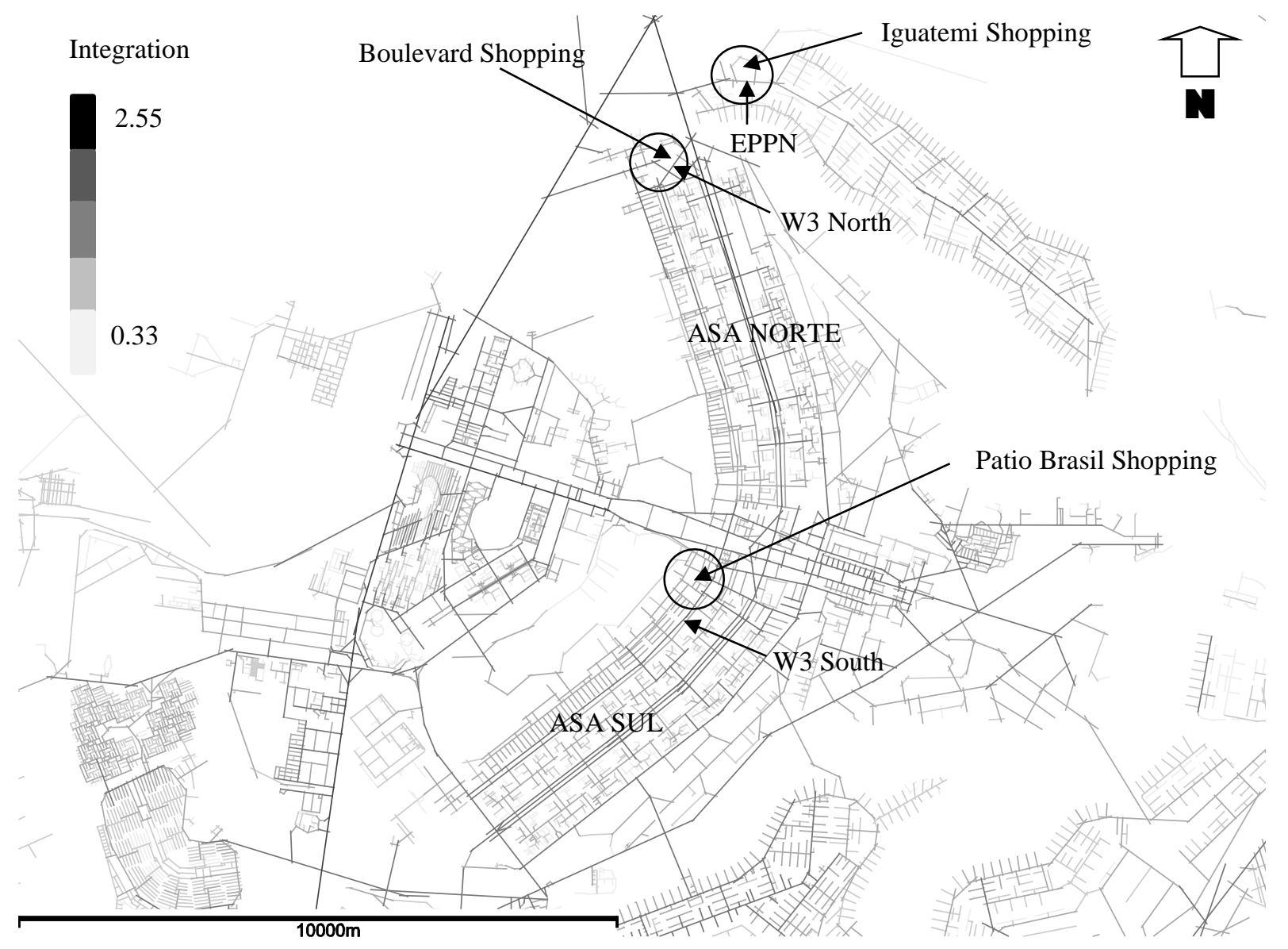

\section{Figure 10 - Axial Map R7 of the Federal District (The Pilot Plan and Lago Norte are highlighted). Source: DIMPU/UnB study group (2009)}

In this sense, the connectivity shows that not always a street with many connections has a high integration value, whether it is global or local. For the three TGDs, it is observed that the axis with the highest global and local integration is W3 North (Boulevard); on the other hand, it has the highest connectivity (7 - Table 2). The same is true for EPPN (Iguatemi), with only 5 direct connections (connectivity) its global integration $(\mathrm{Rn})$ is 0.87 - second highest among the cases studied - and local (R7), coincidentally is the lowest, with the value of 1.62. W3 South (Patio Brasil), in turn, has the highest number of connections (8 - Table 2), however, its global integration is the lowest (0.83) among the three, and the local integration presents an intermediate value (1.69). Hence, it is not the number of connections of a given street which will make it more integrated, but how its relationships are established with the others. 


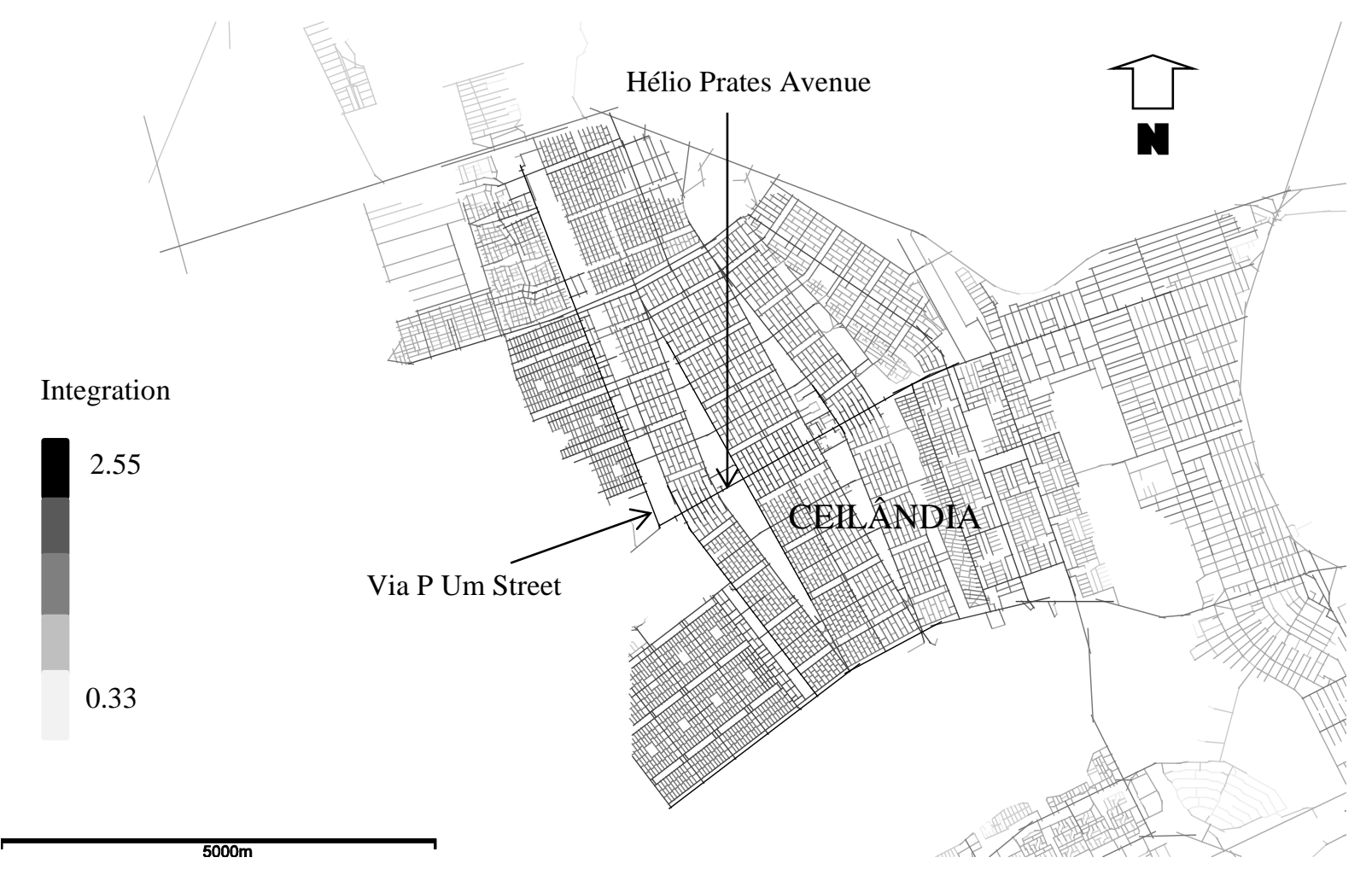

Figure 11 - Axial Map R7 of the Federal District (Ceilândia is highlighted). Source: DIMPU/UnB study group (2009)

It can be observed that in terms of synergy values (Table 3) for the street systems centred on the TGDs and with a 1,000m radius, where Patio Brasil (0.57), o Boulevard (0.70) e o Iguatemi (0.64) are located, the one which presents the smallest variation between global and local values are the ones surrounding Boulevard Mall. Next, there is the street system surrounding Iguatemi Mall in an intermediary position, and finally the one with the worst performance (from the point of view of synergy) is the surroundings of Patio Brasil. In other words, the most synergetic system, the one that presents a better correspondence between the local and global hierarchical aspects, is the one surrounding Boulevard Mall, once the street hierarchy does not present great variations and is thus more legible to people (in terms of legibility/understanding/facility to identify within the urban space).

Comparing the analysis of movement potential, derived from the Space Syntax, with the location of axis through which the public transportation runs, it appears that there is some correspondence. After all, the network of public transportation tends to be deployed on routes of high street hierarchy, and that, according to Barros et al. (2005), the Syntax can be used to define parameters of road hierarchy by means of axial maps. This is corroborated when 
performing the syntactic analysis of the Pilot Plan alone (Figure 12), in which it can be seen that for the case of roads W3 South and W3 North, there is strong integration with the system, with significant presence of different bus lines because they are considered important links from the "centre" of the Pilot Plan to other cities (administrative regions). It is worth noting that according to the DFTRANS (2013), there are at least 27 different bus lines in the W3 South and 20 in W3 North, not counting lines from other cities.

Table 3 - Synergy of the street systems within the $1 \mathrm{~km}$ radius of the TGDs.

\begin{tabular}{ccc}
\hline TGDs & Total number of axes & Sinergy (average) \\
\hline Patio Brasil & 117 & 0.57 \\
Boulevard & 84 & 0.70 \\
Iguatemi & 75 & 0.64 \\
\hline
\end{tabular}

This does not happen in these proportions in EPPN, once it is a peninsula (the shape of the region of Lago Norte where Iguatemi Mall is located), it is not a major connecting route. Therefore, there isn't a strong presence of a transportation system.

In syntactic terms of the peninsula in relation to the system (Federal District), it appears that only with the implementation of the Iguatemi Mall, the movement potential of the region (based on integration index) is indeed used. That is, one has to take into account how spatial relations are established in cities in order to promote the use of strategies that connect (a) hierarchy, (b) centralities and (c) TGDs, when choosing a place to place developments in urban areas.

In terms of transportation, it should be noted that the centralities studied do not resemble the "traditional" ones, for their areas do not present such dimensions that promote a significant and diverse attraction and generation of trips. Therefore, due to the design of the city, such centralities (and others identified by the experts) do not have considerable relevance to the urban system in general, characterised, therefore, as sub-centres (Kneib, 2008). 
Based on the above, it can be inferred that the TGDs have an intermediate location in relation to the urban structure as a whole. Globally and locally speaking, their integration indexes are higher than the averages of the system $(0.67-\mathrm{R} n$ and $1.32-\mathrm{R} 7)$, which means that the hierarchical relationships existing in this structure makes them relatively accessible.

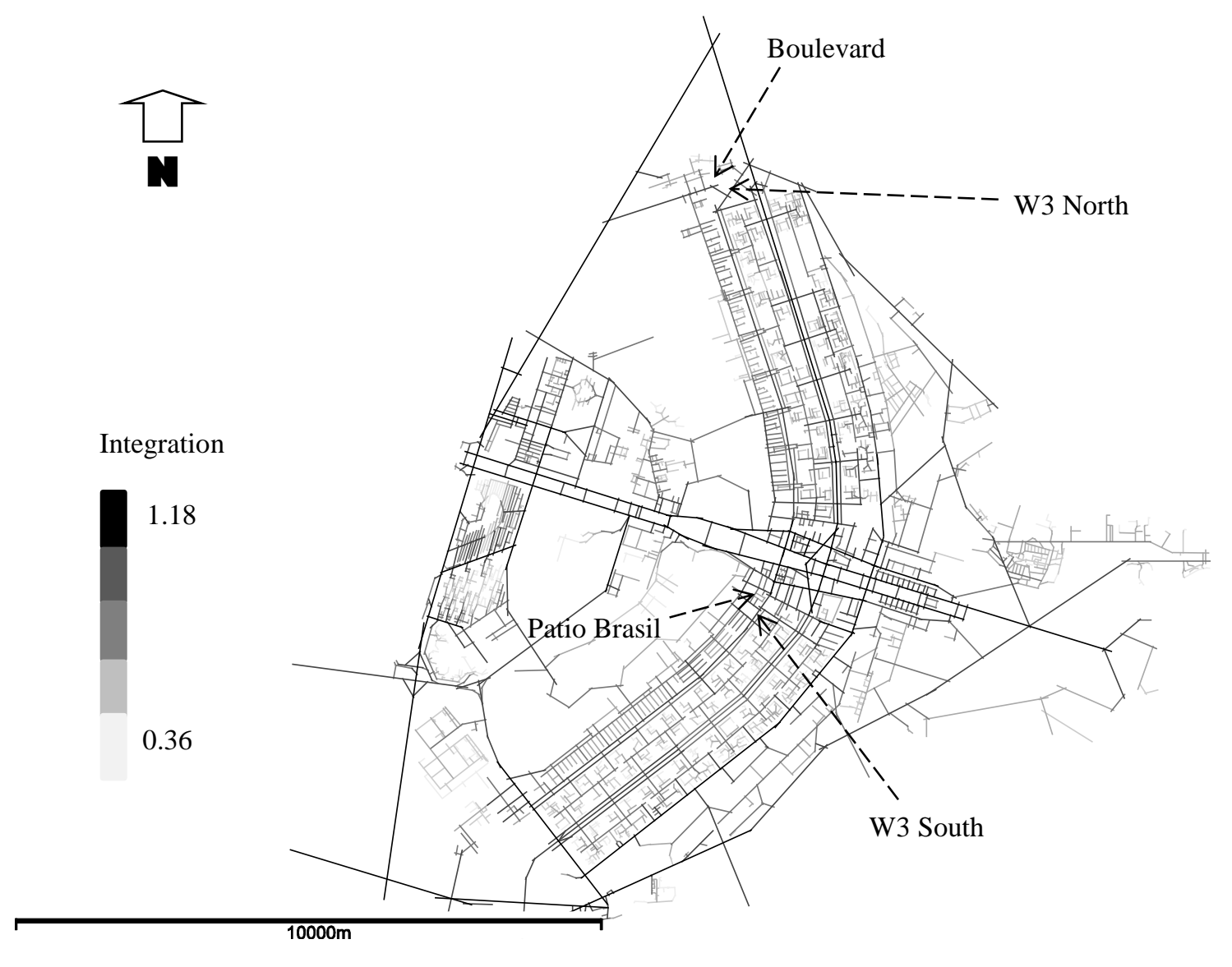

Figure 12 - Axial Map Rn of the Pilot Plan. Source: Barros (2006)

In view of this, we can say that the relations between the parts to the whole of an urban structure are altered depending on the connections in the existing urban fabric. And depending on how this fabric is designed, it can either help or hinder the performance of existing uses in a city. It is pointed out, therefore, that in the case of TGDs in general, these can be benefited or harmed by such relationships. 


\section{Conclusion}

The research analysed the TGDs present in urban centres through the application of tools related to Space Syntax and explored their respective locations in terms of street hierarchy, the potential for movement flow (Integration index) and the volume of traffic (number of vehicles per hour) in the streets that give access to the developments.

Once the Space Syntax Analysis studies how the components of the urban space are related to each other, and thus enable verification of movement potential in all areas of the system, it is a powerful tool to improve the characterisation studies and analysis of existing TGDs. In addition, it can also help in choosing the most appropriate location of future large scale developments. Such aspects were not addressed in this study because there was an exclusive focus on the analysis of the aspects of pre and post implementation of the developments.

In view of this, it can be inferred that the Space Syntax Analysis is important to complement the results of other analyses, and it can be used as a strategic planning tool, supporting thus the decision making process to create measures to foster mobility in urban areas.

We could, therefore, verify that the use of the Experts technique, the comparison between satellite images from Google and volume counting of the traffic on the streets close to the TGDs and the Space Syntax Analysis have allowed for a more consistent analysis. This joint use of scientific methods produce more consistent results which tend to strengthen the interdisciplinary character sometimes overlooked, in addition to expanding the scope of knowledge of a particular area of study. The interdisciplinary scenario enhances, therefore, the way to analyse certain aspects addressed through new perspectives of study.

As recommendations for further and complementary work, it would be important to add the volumetric counting over several years to the trip generation models of TGDs, thus enabling the analysis of the variation in traffic flows in more details as well as the specific impact of developments in the volume of vehicles surveyed, fostering a more consistent and reliable analysis on the impact of TGDs over the urban structure and centralities analysed.

Some other aspects would deserve further analysis in the future, such as the application of the methodology in cities with other designs - the so-called "traditional" or "pre-modern", with 
traditional regular design (chess board), irregular street network (organic), etc. - and thus check whether there is (and what would be) the variations in results, and further replicate analyses for other types of TGDs.

\section{References}

Arrais, T. P. A. (2007) A região como arena política - um estudo sobre a produção da região urbana centro-goiano. Goiânia: EV Editora, Ensaios Regionais.

Aguilera, A. and Mignot, D. (2004) Urban sprawl, polycentrism and commuting. A comparison of seven French urban areas. Urban Public Economics Review. n. 1, pp. 93-113.

Alonso, W. (1964) Location and Land Use. Cambridge, MA: Harvard University Press.

Anas, A., Arnott, R. and Small, K. A. (1997) Urban spatial structure. Working paper UCTC, n. 357. University of California Transportation Center.

Barros, A. P., Medeiros, V. A., Cavalcante, A. P., Silva, P. C. and Holanda, F. (2005) Sintaxe Espacial como ferramenta de definição de parâmetros de hierarquia viária. Anais do XIX Congresso de Pesquisa e Ensino em Transportes - ANPET, Recife, PE, Brasil.

Barros, A. P. (2006) Estudo exploratório da Sintaxe Espacial como ferramenta de alocação de tráfego. Dissertação de Mestrado. FT/PPGT/UnB, Brasília.

Barros, A. P., Kneib, E., Tedesco, G., Paiva, M. and Silva, P. C. (2011) Identificação de centralidades por meio da análise da configuração do espaço na área tombada de Brasília. Anais do $17^{\circ}$ Congresso Brasileiro de Transporte e Trânsito - ANTP, Rio de Janeiro.

Baumont, C., Ertur, C. and Le Gallo, J. (2004) Spatial analysis of employment and population density: the case of the agglomeration of Dijon 1999. Geographical Analysis. vol.36, n. 2, pp.146-177.

Castells, M. (1983) A Questão Urbana. Rio de Janeiro: Paz e Terra.

Chapin, F. S. (1977) Planificación del uso del suelo urbano. Barcelona: Oikos-Tau.

DFTRANS (2013) Sistema de itinerários e horários do transporte público do DF: linhas que funcionam no Plano Piloto. Available at www.sistemas.dftrans.df.gov.br.

Giuliano, G. and Small, K. A. (1991) Subcenters in The Los Angeles Region. Regional Science and Urban Economics, vol. 21, n. 39, pp. 163-182.

Goodwin, L. C. (2002) Weather impacts on arterial traffic flow. Available at ops.fhwa.dot.gov.

Google (2013) Imagens de satélite. Available at www.google.pt/maps/preview.

Gordon, P. and Richardson, H. W. (1996) Beyond polycentricity: The dispersed metropolis, Los Angeles, 1970-1990. Journal of the American Planning Association, vol. 62, n. 3, pp. 289-295.

Hillier, B. and Hanson, J. (1984) The Social Logic of Space. Cambridge: Cambridge University Press.

Holanda, F. R. B. (2001) Teoria do Conhecimento e dos Espaços Construídos. Notas de Aula do Curso de Mestrado em Arquitetura e Urbanismo da Universidade de Brasília. PPGT/FAU/UnB.

Holanda, F. (2002) O Espaço de Exceção. Brasília: EdUnB.

Holanda, F., Kohlsdorf, M. E. and Kohlsdorf, G. (2003) Brasília: da Carta de Atenas à Cidade de Muros. $5^{\circ}$ Seminário DOCOMOMO Brasil - Caderno de Resumos. São Carlos: Departamento. de Arquitetura e Urbanismo, Escola de Engenharia de São Carlos, USP. 
IBGE (2010) Censo demográfico. Available at www.ibge.gov.br/cidadesat.

Kneib, E. C. (2008) Subcentros Urbanos: Contribuição Conceitual e Metodológica à sua definição e Identificação para Planejamento de Transportes. Tese de Doutorado. PPGT/UnB, Brasília.

McDonald, John F. and McMillen, D. P. (1990) Employment subcenters and land values in a polycentric urban area: The case of Chicago. Environment and Planning A, vol. 22, pp. 15611574.

McMillen, D. P. (2001) Polycentric urban structure: The case of Milwaukee. Economic Perspectives. n. Q II, pp. 15-27.

McMillen, D. P. (2004) Employment densities, spatial correlation, and subcenters in large metropolitan areas. Journal of Regional Science, vol.44, Issue 2, pp. 163-182.

Medeiros, V. A (2006) Urbis Brasiliae. Tese de Doutorado. PPG/FAU/UnB, Brasília.

Medeiros, V. A. and Holanda, F. (2010) Brazilian Cities: fragmentary space, patchwork and oasis in the labyrinth. Urban Design International, vol.15, pp. 73-89.

Medeiros, V. and Trigueiro, E. (2001) Disneyfication Now? Proceedings of the Third Space Syntax Simposium. GeogiaTech, Atlanta/USA.

Mills, E. S. (1972) Studies in the Spatial Structure of the Urban Economy. Baltimore, MD: Johns Hopkins: University Press.

Ministério das Cidades (2004) Plano Diretor Participativo. Ministério das Cidades. Brasília.

Muth, R. F. (1969) Cities and Housing. Chicago: University of Chicago Press.

Oliveira Jr, G. A. (2008) Redefinição da Centralidade Urbana em Cidades Médias. Sociedade \& Natureza, Uberlândia, MG.

Perroux, F. (1970) O conceito de polo de crescimento. In: Faissol, S. (1975) Urbanização e Regionalização, Relações com o Desenvolvimento Econômico. Rio de Janeiro, IBGE.

Villaça, F. (2001) Espaço intra-urbano. São Paulo: Studio Nobel.

Wingo (1961) Transportation and Urban Land. Washington, DC: Resources for the Future. 